\title{
Designing the Structure of a General-Purpose Telemedicine Complex
}

\author{
Valerii Semenets \\ ORCID 0000-0001-8969-2143 \\ Department of Biomedical \\ Engineering \\ Kharkiv National University \\ of Radio Electronics \\ Kharkiv, Ukraine \\ valery.semenets@nure.ua \\ Oleg Zubkov \\ ORCID 0000-0002-8528-6540 \\ Department of Microprocessor \\ Technologies and Systems \\ Kharkiv National University \\ of Radio Electronics \\ Kharkiv, Ukraine \\ oleh.zubkov@nure.ua
}

\author{
Valeriia Chumak \\ ORCID 0000-0002-2403-020X \\ Department of Microprocessor \\ Technologies and Systems \\ Kharkiv National University \\ of Radio Electronics \\ Kharkiv, Ukraine \\ valeriia.chumak@nure.ua \\ Oleksandr Vorgul \\ ORCID 0000-0002-7659-8796 \\ Department of Microprocessor \\ Technologies and Systems \\ Kharkiv National University \\ of Radio Electronics \\ Kharkiv, Ukraine \\ oleksandr.vorgul@nure.ua
}

\author{
Iryna Svyd \\ ORCID 0000-0002-4635-6542 \\ Department of Microprocessor \\ Technologies and Systems \\ Kharkiv National University \\ of Radio Electronics \\ Kharkiv, Ukraine \\ iryna.svyd@nure.uas \\ Natalia Boiko \\ ORCID 0000-0002-7524-729X \\ Department of Microprocessor \\ Technologies and Systems \\ Kharkiv National University \\ of Radio Electronics \\ Kharkiv, Ukraine \\ natalia.boiko@nure.ua
}

\begin{abstract}
Taking into account modern trends, the analysis of the construction principles of telemadic systems, networks and complexes is presented in the work. The general structure of providing telemedicine services is developed. Structures of realization of portable and mobile telemedicine complexes are offered. Infocommunication systems and networks for implementation in mobile telemedicine complexes are analyzed. The advantages of using the sensor mobile body area network of the IEEE 802.15.6 WBAN standard in mobile telemedicine complexes are justified.
\end{abstract}

Keywords-telemedicine, telemedicine complex, medical services, device structure, microcontroller, sensor network , wireless sensor body area network

\section{INTRODUCTION}

In modern society, taking into account the current epidemiological situation caused by COVID-19, telemedicine has become widely used, both in the world and, in particular, in Ukraine.

Telemedicine is a new direction of medical services, which is rapidly developing and being implemented in everyday life. Telemedicine covers several diverse areas medicine, telecommunications, information technology. This field of medical services allows the patient and the doctor to save time and effort, because communication takes place online. This is relevant both for residents of megacities and for people living in rural areas. This approach provides equal access to quality health care for patients in all parts of the country. Also, in general, telemedicine significantly reduces the cost of treatment, improves the quality of diagnosis and realizes the possibility of remote monitoring of health, which in turn is economically proven, both for the patient and for the country as a whole [1-3].

As part of the World Health Organization's (WHO) telemedicine policy in 1997, the following definition was proposed. Telemedicine is a method of providing health care services where distance is a critical factor. Services are provided by health professionals using information and communication technologies to obtain the information necessary for the diagnosis, treatment and prevention of diseases [1-5].

\section{DEVELOPMENT OF THE TELEMEDICAL COMPLEX STRUCTURE}

The functional purpose of the telemedicine complex is determined in accordance with the necessary and sufficient requirements for monitoring the patient's condition. And for patients with chronic diseases and the elderly ones, this is extremely important. Also, the telemedicine complex can be used to monitor the condition of athletes during training, fitness training, rehabilitation period and so on.

Monitoring can be classified by purpose, including: heart monitoring; hemodynamic monitoring; respiration monitoring; neurological monitoring; monitoring of blood glucose levels; body temperature control and more.

The telemedicine complex can have a mobile or portable structure. The proposed general structural schemes for the construction of portable / mobile telemedicine complexes are shown in Fig. 1 and Fig. 2.

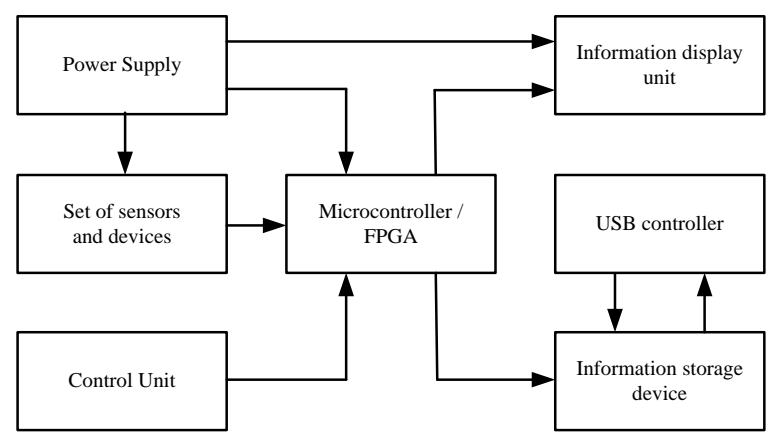

Fig. 1. Portable telemedicine complex. 


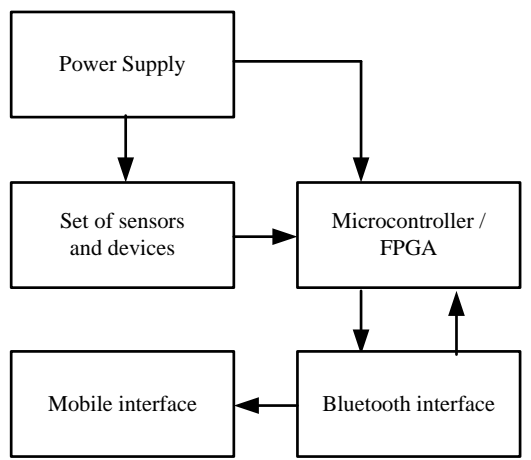

Fig. 2. Mobile telemedicine complex.

According to the analysis conducted, it is advisable to use FPGA and sensor network to develop a telemedicine complex or system [6-11].

In the given structure of a mobile telemedicine complex (fig. 2) it is offered to use a sensor mobile body network of WBAN technology.

WBAN is a sensor mobile body network of the IEEE 802.15.6 standard. The goal of IEEE 802.15.6 standard is to provide an international standard for low-power, short-range, and highly reliable wireless communications within the human body environment, while maintaining a wide range of data rates for a variety of applications. This standard describes short-range wireless communication near or inside the human body (but not limited to humans). It uses existing industrial scientific medical (ISM) bands as well as frequency bands approved by national medical and/or regulatory authorities. It is necessary to maintain quality of service (QoS), extremely low power consumption and data transfer speeds of up to $10 \mathrm{Mbps}$, while adhering to strict rules of non-interference if necessary. This standard considers the effect on portable antennas due to the presence of a person (depending on the man, woman, slim, fat, etc.). The form of the radiation pattern is used to minimize the specific absorption coefficient (SAR) required in the body, as well as changes in characteristics as a result of user actions.

The IEEE 802.15.6 standard aims to ensure confidentiality, authentication, integrity, protection against interference and protection against reproduction. All nodes and hubs must select three security levels: insecure connection (level 0), authentication but without encryption (level 1), and both authentication and encryption (level 2). In the security matching process, the node and the hub must jointly select the appropriate security level. In unicast, the previously shared or new shared key (MK) is activated. Then a paired temporary key (PTK) is created, which is used only once per session. Multicast creates a temporary group key (GTK) that is used in conjunction with the corresponding group. All nodes and hubs in the WBAN must go through certain steps at the MAC level before exchanging data. The procedure used is the security association. This is a procedure to identify the node and the hub for each other; to setup a new shared key (MK) that was shared between them, or to activate an existing MK previously shared between them. The IEEE 802.15.6 security association is based on four key negotiation protocols.

In the IEEE 802.15.6 standard as information carriers it is offered to use pulse signals of three types: pulses with linear frequency modulation (chirp pulses), 58 chaotic pulses (chaotic pulses) short pulses (short pulses shape).

While building IEEE 802.15.6 sensor networks, as for similar IEEE 802.x networks, there is an urgent problem the energy efficiency of the sensors used, which depends on the parameters of the sensor life cycle, network reliability (the probability of data exchange between two nodes in a certain time interval) and the radius transition of the message.

\section{CONCLUSION}

Telemedicine systems implement modern trends in the development of medical services. But they fulfil an important function of real-time biological indicators monitoring in various spheres of medicine and sports by means of telemedicine complexes. It is the fact that indicates the urgency of the tasks for the development of a telemedicine complex of automated control. Such a complex based on a modern microcontroller system or FPGA is going to measure a wide range of biometric indicators and is able to record, transmit and store the collected information. In this complex it is offered to use a sensor mobile body network of the IEEE 802.15.6 standard as a quite reliable wireless communication utility supporting a wide range of data transfer speeds.

\section{REFERENCES}

[1] E. Krupinski, "Telemedicine Workplace Environments: Designing for Success", Healthcare, vol. 2, no. 1, pp. 115-122, 2014. doi: 10.3390/healthcare2010115.

[2] B. Kreofsky, R. Blegen, T. Lokken, S. Kapraun, M. Bushman and B. Demaerschalk, "Sustainable Telemedicine: Designing and Building Infrastructure to Support a Comprehensive Telemedicine Practice", Telemedicine and e-Health, vol. 24, no. 12, pp. 1021-1025, 2018. doi: 10.1089/tmj.2017.0291.

[3] "A Java-based general purpose telemedicine system", International Congress Series, vol. 1256, p. 1302, 2003. doi: 10.1016/s05315131(03)00257-7.

[4] Чумак В.С., Свид I.В. "Реализация структуры нейронных сетей на FPGA", Наука, технологіï, інновації: тенденції розвитку в Україні та світі: матеріали міжнародної студ. наук. конф., 2020. - Харків, Україна: Молодіжна наукова ліга. -Т.2- С. 30-32.

[5] I. Svyd, O. Vorgul, V. Semenets, O. Zubkov, V. Chumak and N. Boiko, "Special Features of the Educational Component Design of Devices on Microcontrollers and FPGA", MC\&FPGA-2020, 2020. doi: 10.35598/mcfpga.2020.017.

[6] O.G. Avrunin, T.V. Nosova, V.V. Semenets. Basics of VDHL language for designing digital devices on FPGA: a textbook. Kharkiv: KNURE, 2018. - 196 p.

[7] В. Чумак, I. Свид. "Створення модуля VHDL-опису при проектуванні цифрових систем на ПЛIC в Xilinx ISE Design Suite", Перспективні напрямки сучасної електроніки, інформаційних $і$ комп'ютерних систем (MEICS-2019), 27-29 листопада 2019 р., м. Дніпро, Україна, 2019, С. 94-95.

[8] V. Semenets, "Technical aspects for development laboratory base for learning FPGA and microcontroller systems.", in 10th International Conference The Experience of Designing and Application of CAD Systems in Microelectronics, Lviv-Polyana, Ukraine, 2009, p. 145.

[9] O. Vorgul, O. Zubkov, I. Svyd and V. Semenets, "Teaching microcontrollers and FPGAs in Quarantine from Coronavirus: Challenges and Prospects", MC\&FPGA-2020, 2020. doi: 10.35598/mcfpga.2020.005.

[10] Z. Oleg, I. Svyd and O. Maltsev, "Features of the use of PID controllers when controlling evaporators", MC\&FPGA-2020, 2020. doi: $10.35598 /$ mcfpga.2020.001.

[11] HusonM. L.; Sen A. Broadcast scheduling algorithms for radionetworks / Military Communications Conf, IEEE MILCOM. 1995. V.2, P. 647-651. 